\title{
THE EFFECTS OF SOIL CONDITIONERS ON GRASS COLOUR THROUGHOUT THE GROWING SEASON
}

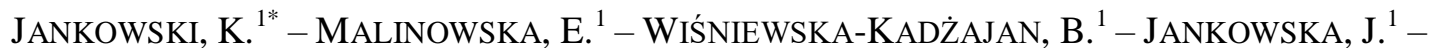

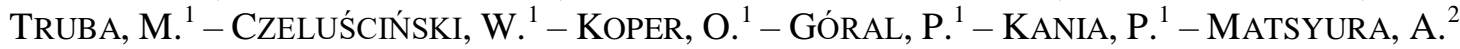 \\ ${ }^{1}$ Department of Grassland and Green Areas Creation, Faculty of Natural Sciences, Siedlce \\ University of Natural Sciences and Humanities, B. Prusa 14 Street, 08-110 Siedlce, Poland
}

\author{
${ }^{2}$ Altai State University \\ Prospekt Lenina 61, 656049 Barnaul, Russia \\ *Corresponding author \\ e-mail: jankowskik@uph.edu.pl
}

(Received 28 ${ }^{\text {th }}$ Mar 2018; accepted $12^{\text {th }}$ Jun 2018)

\begin{abstract}
The aim of this study is to assess soil conditioners' effects on the colour intensity of lawn grass. The field experiment was conducted in the experimental facility between 2013 and 2015 in Poland. The following grass species were used in the experiment (factor B): Lolium perenne, Festuca rubra, and Poa pratensis. Another experimental factor tested in the research was soil conditioners (factor A) as Substral, Humus Active Papka, Eko-Użyźniacz, UGmax. At the end of each growing season between 2013 and 2015 the colour of grasses was assessed in accordance with the methodology using a 9-point rating scale. This assessment was conducted in three seasons: spring, summer, and autumn. In all seasons of the year smooth-stalked meadow-grass had the most favourable colour when treated with Substral in spring and summer seasons, and with Eko-Użyźniacz in autumn. Comparing all soil conditioners, grass treated with UGmax had the best colour. From a practical point of view, of all grass species tested in the study, perennial ryegrass had the smallest, most favourable, colour variation during the whole period.
\end{abstract}

Keywords: leaf-blade greenness, lawns, soil conditioners, turf grasses, growing season

\section{Introduction}

Green spaces positively affect human well-being and mental state not only in dwelling areas but also in workplaces. In addition, to some degree they satisfy inhabitants' aesthetic needs. Regardless of the purpose of a green area, grass is the basic plant to cover the ground in a lawn (Grabowski et al., 2003a; Prończuk and Żurek, 2008; Pooya et al., 2013; Knot et al., 2017). With its richness of species and forms, grass has an amazing ability to adapt to changing weather conditions and different ways of its use (Wolski, 2003; Knot et al., 2017). A lawn should be composed of several species of grass, complementing each other in terms of their properties. Selection of those species should depend on habitat conditions and on the lawn's user capacity to provide means to meet maintenance requirements (Salehi and Khosh-Khui, 2004; Czeluściński et al., 2017). Each species of grass has a unique role in the environment, as well as in human life and economic activity (Pooya et al., 2013; Knot et al., 2017). In Poland there are some 160 species of grass, but out of this considerable number only 16 of them are suitable to plant lawns (Grabowski et al., 2003a; Prończuk and Żurek, 2008). The most common grass species used for extensive lawns include: red fescue (Festuca rubra), smooth-stalked meadow-grass (Poa pratensis), and perennial ryegrass (Lolium perenne). These species have a varied degree of leaf-blade greenness. In general, red fescue, as opposed to the other two 
species, is a dark green plant. Naturally, an important element in determining the appearance of a lawn is its colour (Jankowski et al., 2012a, b; Braun et al., 2016), which can change under the influence of the weather, habitat, and other conditions. Difficulty in maintaining a proper grass colour under adverse moisture conditions or with insufficient nutrients in the soil can cause a loss of a lawn's natural greenness and, consequently, its attractiveness can be significantly reduced. Green is a calming and beneficial colour for the human eye, positively affecting mental health. In degraded areas there is a much higher rate of people suffering because of the direct action of pollutants, but there is also a significant increase in mental health problems resulting from stress caused by a lack of contact with nature (Stępczak, 1997; Salehi et al., 2004; Knot et al., 2017).

As a result of the presence of green spaces, negative effects of long lasting droughts can be reduced. However, longer periods with little rainfall lead to a change of lawn colour from green to yellow, with some grass leaves turning discoloured (Prończuk and Żurek, 2008; Braun et al., 2016). When adequate care and conditions cannot be provided, an application of soil conditioners before setting up a lawn can be a good solution. The quality of the turf with its colour depends to a large extent on a frequent application of plant nutrients which can stimulate quality and colour of the grass (Jankowski et al., 2010, 2011a, b, c). Additionally, leaf colour, apart from leaf fineness, is an indicator most often assessed in lawns. Grass with narrow dark green leaves looks the best (Jankowski et al., 2012a), and this is the colour most desired by lawn users. Plant physiological processes can be modified by mineral compounds stimulating plant growth. Soil conditioners are based on natural substances such as plant or humus extracts and phytohormones (Hamza and Suggars, 2001). Those bio fertilizers demonstrate a positive impact on grass metabolism, stimulate life processes, and reduce the effects of adverse environmental conditions (drought, salinity, temperature fluctuations) and pathogens (Chen et al., 2004; Gąbka and Wolski, 2008). Soil conditioner application contributes to the decomposition of organic matter. This is a very important effect due to the release of mineral forms, which are an important source of nutrients for arable crops (Hamza and Suggars, 2001; Chen et al., 2004; Calvo et al., 2014). Soil conditioners used instead of mineral fertilizers can play an essential role in grass ecological maintenance, and the aim of this study is to assess their effects on the colour intensity of lawn grass.

\section{Materials and methods}

\section{Experimental design}

Set up in 2012 the field experiment was conducted in Poland in the experimental facility of the University of Natural Sciences and Humanities in Siedlce $\left(52^{\circ} 12^{\prime} \mathrm{N}\right.$, $22^{\circ} 28^{\prime}$ E) between 2013 and 2015. The research was carried out as a mini-plot experiment, in the split plot design with three replications and the plot area of $1 \mathrm{~m}^{2}$. The following grass species were used in the experiment (factor B): Lolium perenne variety Info, Festuca rubra - variety Nil, and Poa pratensis - variety Alicja. They were sown on their own, each of them at the rate of $28 \mathrm{~g} \cdot \mathrm{m}^{2}$. Another experimental factor tested in the research was soil conditioners (factor A).

Soil conditioners used in the experiment improve soil properties, according to the Institute of Soil Science and Plant Cultivation (IUNG) in Puławy. The composition of the soil conditioners used in the research is presented in Table 1. 
Table 1. Composition of soil conditioners applied in the experiment

\begin{tabular}{|c|c|c|c|c|c|c|c|c|c|c|c|c|}
\hline \multirow{2}{*}{$\begin{array}{c}\text { Soil } \\
\text { conditioner }\end{array}$} & \multicolumn{6}{|c|}{ Macronutrients $\left(\mathrm{g} \cdot \mathrm{kg}^{-1}\right)$} & \multicolumn{5}{|c|}{ Micronutrients $\left(\mathrm{mg} \cdot \mathrm{kg}^{-1}\right)$} & \multirow{2}{*}{$\begin{array}{l}\text { Microorganism } \\
\text { and others }\end{array}$} \\
\hline & $\mathbf{N}$ & $\mathbf{P}$ & $\mathbf{K}$ & $\mathrm{Ca}$ & Mg & $\mathbf{N a}$ & Mn & $\mathbf{F e}$ & $\mathbf{Z n}$ & $\mathbf{C u}$ & Mo & \\
\hline Substral (S) & 220 & 21.8 & 83 & & 12.06 & & 12 & 50 & 12.5 & 12.5 & 1 & - \\
\hline $\mathrm{g} \cdot \mathrm{m}^{-2}$ & 4.4 & 0.44 & 1.66 & & & & & & & & & \\
\hline $\begin{array}{c}\text { Humus } \\
\text { Active Papka } \\
\text { (HAP) }\end{array}$ & 0.2 & 1.3 & 4.6 & 3.0 & 0.5 & - & 15 & 500 & 3 & 1 & - & $\begin{array}{l}\text { Active humus with } \\
\text { useful } \\
\text { microorganisms }\end{array}$ \\
\hline $\mathrm{g} m^{-2}$ & 0.05 & 0.33 & 1.15 & & & & & & & & & \\
\hline $\begin{array}{c}\text { Eko- } \\
\text { Użyźniacz } \\
\text { (EU) }\end{array}$ & 0.6 & 0.3 & 0.7 & - & - & - & - & - & - & - & - & $\begin{array}{l}\text { Endo micorhiza, } \\
\text { fungi, bacteria, } \\
\text { enzymes of } \\
\text { earthworms }\end{array}$ \\
\hline $\mathrm{g} \cdot \mathrm{m}^{-2}$ & 0.06 & 0.03 & 0.07 & & & & & & & & & \\
\hline $\operatorname{Ugmax}(\mathrm{UG})$ & 1.2 & 0.2 & 2.9 & - & 0.1 & 0.2 & 0.3 & - & - & - & - & $\begin{array}{c}\text { Lactic acid } \\
\text { bacteria, } \\
\text { photosynthetic } \\
\text { bacteria, } \\
\text { Azotobacter, } \\
\text { Pseudomonas, } \\
\text { yeast, } \\
\text { Actinomycetes }\end{array}$ \\
\hline $\mathrm{g}^{\prime-2}$ & 0.03 & 0.01 & 0.07 & & & & & & & & & \\
\hline
\end{tabular}

The UGmax soil conditioner is an extract from compost, containing macronutrients $(\mathrm{N}, \mathrm{P}, \mathrm{K}, \mathrm{Mg}, \mathrm{Na})$ and micronutrients $(\mathrm{Mn})$. It also contains lactic acid bacteria, photosynthetic bacteria, Azotobacter, Pseudomonas, yeast, and Actinomycetes. The micro-organisms in the conditioner have a capacity of processing organic and natural fertilizers into compost and humus. These processes are conducive not only to the production of humus but also to improving soil structure, which in turn has a positive effect on water balance in the soil. In addition, the UGmax soil conditioner increases disease resistance, keeping plants healthy, but it also stimulates the development of the root system and supports the biological reduction of molecular nitrogen.

Humus Active Papka contains macronutrients (N, P, K, Ca, Mg), trace elements (Mn, $\mathrm{Fe}, \mathrm{Zn}, \mathrm{Cu}$ ), and active humus with useful microorganisms. According to the manufacturer Humus Active, among other beneficial effects, positively affects plant health as well as soil structure, and releases nutrients not readily available to plants.

Eko-Użyźniacz is extracted from bovine vermicompost and contains the main macronutrients (N, P, K), micro-organisms, and enzymes related to metabolism of earthworms. This soil conditioner stimulates biological life in soil degraded chemically, mechanically, or biologically, and increases plant resistance to different stress factors.

Soil conditioners were applied annually in spring (mid May) in the following doses: UGmax - $25 \mathrm{ml} \mathrm{m}^{-2}$ (0.6 1 in 2501 of water), Eko-Użyźniacz - $100 \mathrm{ml} \mathrm{m}^{-2}$ (10 1 in 1001 of water), and Humus Active Papka $-250 \mathrm{ml} \mathrm{m}^{-2}$ (0.2 1 for 101 of water). In turn, Substral, a slow release fertilizer used on lawns, was used in the quantity of $20 \mathrm{~g} \mathrm{~m}^{-2}$. The tested fertilizers were used in doses recommended by the manufacturer.

At the end of each growing season between 2013 and 2015 an assessment of grass based on the methods described by Domański (1998) was carried out. Among other 
things its colour was assessed in accordance with the methodology using a 9-point rating scale (Table 2). This assessment was conducted in three seasons: spring, summer, and autumn. In each year of the research spring assessment was made around 20 May, summer assessment around 20 August, and autumn assessment around 10 October.

The experiment was set up on the soil developed from loamy sand, belonging to anthropogenic soils of the culture-earth order, and of the type of hortisole (Systematics of Polish Soils, 2011). Chemical analysis showed that the soil was of neutral $\mathrm{pH}$ $(\mathrm{pH}=6.8)$, with assimilable phosphorus in a form of $\mathrm{H}_{2} \mathrm{PO}_{4}$ - standing at $170 \mathrm{mg} \cdot \mathrm{kg}^{-1}$, magnesium $\mathrm{Mg}^{2+}$ at $84 \mathrm{mg} \cdot \mathrm{kg}^{-1}$, potassium $\mathrm{K}^{+}$at $114 \mathrm{mg} \cdot \mathrm{kg}^{-1}$, total nitrogen $\mathrm{N}$ at 1.3 $\mathrm{g} \cdot \mathrm{kg}^{-1}$, and organic carbon at $13.5 \mathrm{~g} \cdot \mathrm{kg}^{-1} \mathrm{DM}$.

Table 2. Lawn grass colour rating with a scale of 1 to 9 according to Domański (1998)

\begin{tabular}{c|c}
\hline Rating & Grass colour \\
\hline 1 & Bare ground with no grass \\
2 & Dry grass \\
3 & Yellowish to brownish green \\
4 & Yellowish green with discolouration \\
5 & Greyish green \\
6 & Bluish green \\
7 & Light green \\
8 & Lush green \\
9 & Dark green \\
\hline
\end{tabular}

\section{Statistical analysis}

The test results were evaluated statistically with the analysis of variance. Tukey's test $(\mathrm{P} \leq 0.5)$ was used to find significantly different means of the effects of experimental factors and their interaction. Based on lawn colour ratings, standard deviation and coefficient of variation were calculated for separate seasons, years, and soil conditioners.

\section{Weather conditions}

Meteorological data between 2013 and 2015 were obtained from the Hydrological and Meteorological Station in Siedlce (about $4 \mathrm{~km}$ from experimental station). In order to determine the temporal variation of meteorological elements and their effects on vegetation, Sielianinov's hydrothermal coefficient was calculated on the basis of monthly rainfall $(\mathrm{P})$ and the monthly total air temperature $(\Sigma \mathrm{t})$, using the formula: $\mathrm{K}=\mathrm{P} / 0.1 \Sigma \mathrm{t}$ (Skowera and Puła, 2004).

In assessing temperature and moisture conditions ten-scale classification of Sielianinov's hydrothermal coefficient $(\mathrm{K})$ was used, which, according to Skowera and Puła (2004), has the following ranges:

$\mathrm{K} \leq 0.4$ extremely dry (ed);

$0.4<\mathrm{K} \leq 0.7$ very dry (vd);

$0.7<\mathrm{K} \leq 1.0$ dry $(\mathrm{d})$; 
$1.0<\mathrm{K} \leq 1.3$ quite dry (qd);

$1.3<\mathrm{K} \leq 1.6$ optimal (o);

$1.6<\mathrm{K} \leq 2.0$ quite wet (qw);

$2.0<\mathrm{K} \leq 2.5$ wet $(\mathrm{w})$;

$2.5<\mathrm{K} \leq 3.0$ very wet $(\mathrm{vw})$;

$\mathrm{K}>3.0$ extremely wet (ew).

The values of Sielianinov's hydrothermal coefficient for individual months of the experiment are shown in Table 3. It was assumed that the conditions were extreme when coefficient values were below 0.7 and above 2.5 (Skowera and Puła, 2004).

Optimal temperature and moisture conditions were only in April 2014 and in September 2015. In the remaining months of all the growing seasons the weather conditions were not as favourable, varying from extremely dry in August 2015 to extremely wet in May 2013. Throughout the experiment the best conditions occurred at the beginning of each growing season. It can be concluded that the most difficult period for plants was in 2015, when, apart from May and the end of the growing season, the weather conditions ranged from quite dry to extremely dry.

Table 3. Sielianinov's hydrothermal coefficient (K) during the growing season

\begin{tabular}{c|c|c|c|c|c|c|c}
\hline \multirow{2}{*}{ Years } & \multicolumn{7}{|c}{ Month } \\
\cline { 2 - 8 } & Apr. & May & June & July & Aug. & Sept. & Oct. \\
\hline 2013 & $2.56(\mathrm{vw})$ & $3.07(\mathrm{ew})$ & $2.11(\mathrm{w})$ & $0.84(\mathrm{~d})$ & $0.78(\mathrm{~d})$ & $2.53(\mathrm{vw})$ & $0.60(\mathrm{vd})$ \\
2014 & $1.36(\mathrm{o})$ & $1.87(\mathrm{qw})$ & $1.64(\mathrm{qw})$ & $0.59(\mathrm{vd})$ & $1.92(\mathrm{qw})$ & $0.64(\mathrm{vd})$ & $0.12(\mathrm{ed})$ \\
2015 & $1.22(\mathrm{qd})$ & $2.63(\mathrm{vw})$ & $0.87(\mathrm{~d})$ & $1.08(\mathrm{qd})$ & $0.18(\mathrm{ed})$ & $1.46(\mathrm{o})$ & $1.94(\mathrm{qw})$ \\
\hline
\end{tabular}

\section{Results}

One of the most important characteristics rated in lawn quality assessment is its colour. In the present study, assessment done in spring seasons (Table 4) proved that grass colour was dependent on the species, the type of soil conditioner, and meteorological conditions.

Comparing soil conditioner effects it was observed that in spring grass was the most intensely green $\left(7.86^{\circ}\right)$ on plots where Substral was applied, being the least intensely green as a result of Eko-Użyźniacz $\left(6.05^{\circ}\right)$ or Humus Active Papka $\left(6.08^{\circ}\right)$ application. Despite that, statistical analysis showed that differences between colour ratings of lawns treated with different kinds of soil conditioner were not significant.

Similarly, the differences between the colour ratings of grass species were not statistically significant either, although smooth-stalked meadow-grass and red fescue had slightly more intense colour than perennial ryegrass, with their ratings of $6.97^{\circ}$ and $6.94^{\circ}$, which is bright green.

The forms of soil conditioners affected the colour of different grass species to a different extent. It was observed that Substral application resulted in leaf blades with the darkest shade of green for all grass species, but smooth-stalk meadow-grass was of the most intense colour $\left(8.13^{\circ}\right)$. In spring seasons, out of all conditioners UGmax application resulted in the most favourable colour of leaf blades in all species, with the average rating of above 7 , indicating light green colour. Throughout all growing seasons it turned out that in the spring, grass was the greenest in 2015 , with the rating of $7.45^{\circ}$, as the average score of all three types of soil conditioners. 
Table 4. Assessment of grass colour (a 9-point scale) between 2013 and 2015 in the spring

\begin{tabular}{|c|c|c|c|c|c|c|}
\hline \multirow{2}{*}{$\begin{array}{c}\text { Year } \\
\text { (C) }\end{array}$} & \multirow{2}{*}{ Species (B) } & \multicolumn{4}{|c|}{ Soil conditioner $(\mathrm{A})$} & \multirow{2}{*}{$\bar{x}$} \\
\hline & & (S) & $(\mathbf{E U})$ & (HAP) & (UG) & \\
\hline \multirow{3}{*}{2013} & Smooth-stalked meadow-grass & 6.6 & 5.9 & 3.8 & 4.2 & 5.13 \\
\hline & Perennial ryegrass & 7.2 & 4.9 & 7.1 & 5.3 & 6.13 \\
\hline & Red fescue & 7.8 & 8.1 & 8.2 & 5.9 & 7.5 \\
\hline \multirow{3}{*}{2014} & Smooth-stalked meadow-grass & 8.8 & 6.1 & 5.9 & 8.9 & 7.43 \\
\hline & Perennial ryegrass & 8.8 & 3.9 & 3.7 & 8.9 & 6.33 \\
\hline & Red fescue & 8.7 & 3.8 & 4.1 & 9 & 6.4 \\
\hline \multirow{3}{*}{2015} & Smooth-stalked meadow-grass & 9 & 8 & 7.8 & 8.7 & 8.38 \\
\hline & Perennial ryegrass & 7.2 & 6.8 & 7.2 & 7 & 7.05 \\
\hline & Red fescue & 6.7 & 7 & 7 & 7 & 6.93 \\
\hline & & \multicolumn{5}{|c|}{ Species effect-mean values } \\
\hline \multicolumn{2}{|c|}{ Smooth-stalked meadow-grass } & 8.13 & 6.66 & 5.83 & 7.26 & 6.97 \\
\hline \multicolumn{2}{|r|}{ Perennial ryegrass } & 7.73 & 5.2 & 6.0 & 7.07 & 6.5 \\
\hline \multicolumn{2}{|r|}{ Red fescue } & 7.73 & 6.3 & 6.43 & 7.3 & 6.94 \\
\hline & & \multicolumn{5}{|c|}{ Fertilizer effect-mean values } \\
\hline & & 7.86 & 6.05 & 6.08 & 7.21 & 6.8 \\
\hline & & \multicolumn{5}{|c|}{ Growing season effect-mean values } \\
\hline & 2013 & 7.2 & 6.3 & 6.36 & 5.13 & 6.25 \\
\hline & 2014 & 8.76 & 4.6 & 4.56 & 8.93 & 6.71 \\
\hline & 2015 & 7.63 & 7.26 & 7.33 & 7.56 & 7.45 \\
\hline \multicolumn{7}{|l|}{$\mathrm{LSD}_{0,05}$} \\
\hline $\mathrm{A}=\mathrm{ns}$ & \multirow{3}{*}{\multicolumn{6}{|c|}{$\begin{array}{l}\mathrm{C}=\mathrm{ns} \\
\mathrm{A} / \mathrm{C}=1.96 \\
\mathrm{C} / \mathrm{B}=1.53\end{array}$}} \\
\hline $\mathrm{A} / \mathrm{B}=\mathrm{ns}$ & & & & & & \\
\hline $\mathrm{C} / \mathrm{A}=1$. & & & & & & \\
\hline
\end{tabular}

Grass colour considerably improved in summer seasons compared with spring periods (Table 5). The results indicated that in summer seasons grass treated with Substral $\left(8.95^{\circ}\right)$ and UGmax $\left(8.84^{\circ}\right)$ had dark green colour, with lawns treated with those two soil conditioners having the most favourable appearance. Grass colour in plots with Eko-Użyźniacz and Humus Active Papka was rated considerably lower, with a score statistically different from the ratings of the other two soil conditioners.

Comparing the colours of different grass species, it was observed that in summer seasons there was no statistically significant difference between them, with the average rating of above 8 for all species, although red fescue had the best colour $\left(8.23^{\circ}\right)$. Grass strongly responded with increased greenness of leaf blades to the application of Substral and UGmax, which was proved by comparing average colour ratings of the three grass species treated with those two conditioners. Those ratings were over $8.8^{\circ}$ for both soil conditioners, indicating dark green colour.

Additionally, the weather conditions in summer seasons affected colour intensity of the grass tested in the study. In the 2014 and 2015 growing seasons grass had the most intense dark green colour (above $8.8^{\circ}$ ), while in 2013 it was much lighter, with the rating of $6.62^{\circ}$, indicating bluish green. The difference in grass colour between all the above growing seasons was statistically significant. 
Table 5. Assessment of grass colour (a 9-point scale) between 2013 and 2015 in the summer

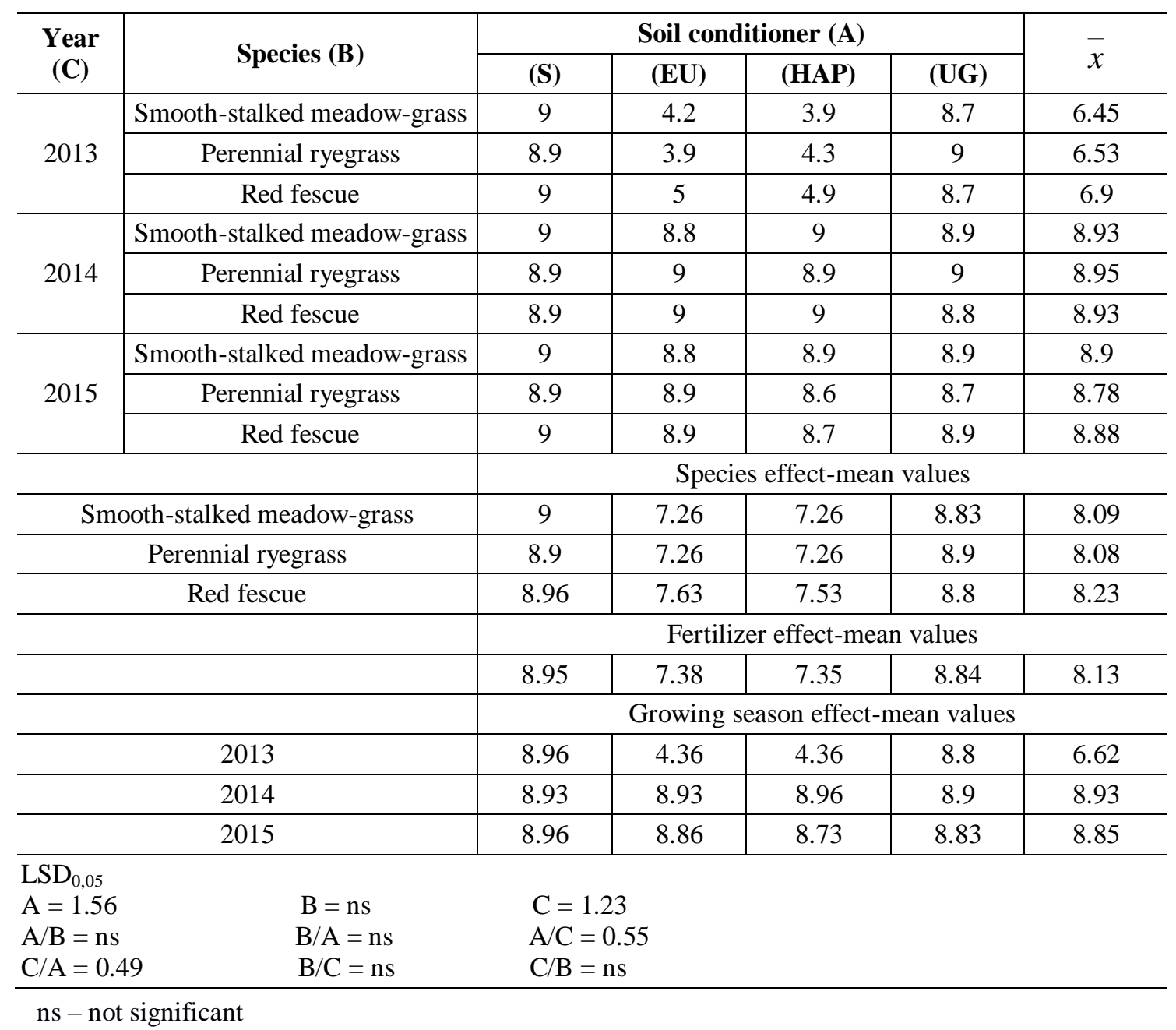

During autumn seasons quite variable grass colours were observed (Table 6). Comparing the types of soil conditioners, Eko-Użyźniacz application resulted in the best colour of grass $\left(6.51^{\circ}\right)$. Grass fertilised with Substral had the least favourable colour during in the autumn $\left(5.87^{\circ}\right)$. However, the differences between the effects of different conditioners were not statistically significant. Contrary to that, there were significant differences between grass species in their shades of green in autumn seasons. Perennial ryegrass had the best colour, with the rating of $7.07^{\circ}$, which was significantly better than for other species of grass.

The grass had the best dark-green colour in 2013 with the rating of above 8.7 as the average of the effects of all conditioners. High rainfall in September 2013 had a huge impact on grass colour, but in the autumn of 2014 and 2015 grass had significantly lower colour rating. The difference in colour ratings between the grass in autumn of 2013 and of the other two years was statistically significant. Comparing the average colour ratings of grass species in all growing seasons (Table 7) it was found that perennial ryegrass had the most advantageous colour $\left(7.22^{\circ}\right)$. Taking into account the type of applied soil conditioner, perennial ryegrass treated with Substral $\left(7.89^{\circ}\right)$ and smooth-stalked meadow-grass treated with Humus Active Papka had the highest colour rating of $6.07^{\circ}$. 
Table 6. Assessment of grass colour (a 9-point scale) between 2013 and 2015 in the autumn

\begin{tabular}{|c|c|c|c|c|c|c|}
\hline \multirow{2}{*}{$\begin{array}{c}\text { Year } \\
\text { (C) }\end{array}$} & \multirow{2}{*}{ Species (B) } & \multicolumn{4}{|c|}{ Soil conditioner $(\mathrm{A})$} & \multirow{2}{*}{$\bar{x}$} \\
\hline & & (S) & $(\mathbf{E U})$ & (HAP) & (UG) & \\
\hline \multirow{3}{*}{2013} & Smooth-stalked meadow-grass & 9 & 8.9 & 8.8 & 8.6 & 8.83 \\
\hline & Perennial ryegrass & 8.9 & 8.8 & 8.5 & 9 & 8.8 \\
\hline & Red fescue & 9 & 8.9 & 8.8 & 8.6 & 8.83 \\
\hline \multirow{3}{*}{2014} & Smooth-stalked meadow-grass & 3 & 3 & 2.8 & 4.1 & 3.23 \\
\hline & Perennial ryegrass & 4.9 & 6.2 & 6 & 5.1 & 5.55 \\
\hline & Red fescue & 5 & 6 & 5.9 & 4.7 & 5.4 \\
\hline \multirow{4}{*}{2015} & Smooth-stalked meadow-grass & 4 & 9 & 3.8 & 4.2 & 5.25 \\
\hline & Perennial ryegrass & 7.2 & 6 & 6.9 & 7.4 & 6.88 \\
\hline & Red fescue & 1.9 & 1.8 & 2 & 2.3 & 2 \\
\hline & & \multicolumn{5}{|c|}{ Species effect-mean values } \\
\hline \multicolumn{2}{|c|}{ Smooth-stalked meadow-grass } & 5.33 & 6.96 & 5.13 & 5.63 & 5.76 \\
\hline \multicolumn{2}{|r|}{ Perennial ryegrass } & 7 & 7 & 7.13 & 7.16 & 7.07 \\
\hline \multicolumn{2}{|r|}{ Red fescue } & 5.3 & 5.56 & 5.56 & 5.2 & 5.41 \\
\hline & & \multicolumn{5}{|c|}{ Fertilizer effect-mean values } \\
\hline & & 5.87 & 6.51 & 5.94 & 6 & 6.08 \\
\hline & & \multicolumn{5}{|c|}{ Growing season effect-mean values } \\
\hline & 2013 & 8.96 & 8.86 & 8.7 & 8.73 & 8.81 \\
\hline & 2014 & 4.3 & 5.07 & 4.9 & 4.63 & 4.72 \\
\hline & 2015 & 4.36 & 5.6 & 4.23 & 4.63 & 4.71 \\
\hline \multicolumn{7}{|l|}{$\mathrm{LSD}_{0,05}$} \\
\hline $\mathrm{A}=\mathrm{ns}$ & $\mathrm{B}=1.55$ & \multirow{3}{*}{\multicolumn{5}{|c|}{$\begin{array}{l}\mathrm{C}=1.55 \\
\mathrm{~A} / \mathrm{C}=\mathrm{ns} \\
\mathrm{C} / \mathrm{B}=2.12\end{array}$}} \\
\hline $\mathrm{A} / \mathrm{B}=\mathrm{ns}$ & $\mathrm{B} / \mathrm{A}=\mathrm{ns}$ & & & & & \\
\hline $\mathrm{C} / \mathrm{A}=\mathrm{ns}$ & $\mathrm{B} / \mathrm{C}=2.12$ & & & & & \\
\hline
\end{tabular}

ns - not significant

Table 7. Effect of soil conditioners on grass colour (a 9-point scale) between 2013 and 2015 mean values

\begin{tabular}{|c|c|c|c|c|c|}
\hline \multirow{2}{*}{ Species (B) } & \multicolumn{4}{|c|}{ Soil conditioner $(A)$} & \multirow{2}{*}{$\bar{x}$} \\
\hline & (S) & $(\mathbf{E U})$ & (HAP) & (UG) & \\
\hline Smooth-stalked meadow-grass & 7.49 & 6.96 & 6.07 & 7.24 & 6.94 \\
\hline Perennial ryegrass & 7.89 & 6.49 & 6.8 & 7.71 & 7.22 \\
\hline \multirow[t]{3}{*}{ Red fescue } & 7.33 & 6.5 & 6.5 & 7.1 & 6.86 \\
\hline & \multicolumn{5}{|c|}{ Fertilizer effect-mean values } \\
\hline & 7.56 & 6.65 & 6.46 & 7.35 & 7.01 \\
\hline \multicolumn{6}{|l|}{$\begin{array}{lll}\mathrm{LSD}_{0,05} & \mathrm{~A}=0.81 \quad \mathrm{~B}=\mathrm{ns} \\
\end{array}$} \\
\hline & \multicolumn{5}{|c|}{ Growing season effect-mean values } \\
\hline 2013 & 8.37 & 6.51 & 6.47 & 7.55 & 7.23 \\
\hline 2014 & 7.33 & 6.2 & 6.14 & 7.49 & 6.79 \\
\hline 2015 & 6.98 & 7.24 & 6.76 & 7.01 & 7.0 \\
\hline $\mathrm{LSD}_{0,05} \quad \mathrm{~A}=\mathrm{ns}$ & & & & & \\
\hline
\end{tabular}

ns - not significant 
Grass treated with Substral had the most favourable lush green colour, with the rating of $7.56^{\circ}$, as the average for all the species, but when it was treated with Humus Active Papka the rating was the lowest, with blue shade of green $\left(6.46^{\circ}\right)$.

Comparing the three years of research, without a division into seasons of the year, it was observed that the grass had the highest colour rating in $2013\left(7.23^{\circ}\right)$ and the lowest in $2014\left(6.79^{\circ}\right)$. The coefficient of variation of grass colours calculated during the research (Table 8$)$ indicated that during the whole research period perennial ryegrass had the smallest variation of the intensity of greenness, and, at the same time, it was characterised by the highest average colour rating of $7.22^{\circ}$, which is light green colour.

Table 8. Standard deviation and coefficient of variation of grass colour

\begin{tabular}{c|c|c|c|c|c}
\hline Species & $\begin{array}{c}\text { Min. value of } \\
\text { colour rating }\end{array}$ & $\begin{array}{c}\text { Max. value of } \\
\text { colour rating }\end{array}$ & $\begin{array}{c}\text { Mean values of } \\
\text { colour rating }\end{array}$ & $\begin{array}{c}\text { Standard } \\
\text { deviation }\end{array}$ & $\begin{array}{c}\text { Coefficient of } \\
\text { variation }\end{array}$ \\
\hline $\begin{array}{c}\text { Smooth-stalked meadow- } \\
\text { grass }\end{array}$ & 2.8 & 9 & 6.94 & 2.35 & 33.86 \\
$\begin{array}{c}\text { Perennial ryegrass } \\
\text { Red fescue }\end{array}$ & 3.7 & 9 & 7.22 & 1.77 & 24.52 \\
\hline
\end{tabular}

Coefficient of variation: 0-20\% small variation, $20-40 \%$ moderate variation, $40-60 \%$ large variation, $>60 \%$ very large variation

\section{Discussion}

In this study the differences between the colour ratings of grass species in spring were not significant, although smooth-stalked meadow-grass and red fescue had slightly more intense colour than perennial ryegrass. But in the studies, of Starczewski and Affek-Starczewska (2011) the cultivars of perennial ryegrass were characterized by the most intensive green at the beginning of the growing season (vivid green in May), and the least favorable in the summer month (grey, dirty green) than other species.

In summer seasons the best green colour had red fescue, but not significant to the other species. In this study in autumn seasons, there were significant differences between grass species in their shades of green but perennial ryegrass had the best colour. Also in the studies by Grabowski et al. (1999) and Jankowski et al. (1999) cultivars of perennial ryegrass achieved the highest marks of colour assessment in autumn periods.

Comparing the average colour ratings of grass species in all growing seasons, it was found that perennial ryegrass had the most advantageous colour. In regard to soil conditioner effects it was observed that in spring and in summer grass was the most intensely green on plots where Substral was applied, being the least intensely green as a result of Eko-Użyźniacz or Humus Active Papka application. According to Jankowski et al. (2012a) the colour of a lawn is an unstable characteristic, depending, among others, on habitat conditions, the content of macro- and micronutrients in the soil, and on their availability for plants. Soil conditioners make absorption of nutrients easier, which affects metabolism of plants (Calvo et al., 2014). Studies conducted by TalarKrasa and Świerszcz (2015) confirm stimulating properties of humic acids present in soil conditioners on plant growth and development as well as grass colour. In the case of the colour of the species studied in the present experiment, application of soil conditioners resulted in a significant increase in leaf blade greenness. In the spring and in summer the best green colour was after Substral application. 
Comparing the types of soil conditioners in autumn, Eko-Użyźniacz application resulted in the best colour of grass. Also in the study of Wiśniewska-Kadżajan (2013) the intensity of the green colour of turf lawns has improved with the increase of the applied dose of mushrooms substrate. According to Jankowski et al. (2012b) the type and amount of fertilizers applied had a big impact on the intensity of the colour. In the other study of Jankowski et al. (2011d) a significantly better effect of fertilizer Sierrablen on the colour of monoculture turfs was observed as compared with Trawovit Komplet.

As the average for all the species, grass treated with Substral had the most favourable lush green colour, but when it was treated with Humus Active Papka the rating was the lowest, with blue shade of green. Braun et al. (2016) studied the stability of dark-green colour of grass leaves over the entire period of vegetation together with greenness durability into late autumn, and observed that it was also dependent on the application of proper fertilizers.

The weather conditions in spring, summer and autumn seasons of each experimental year affected colour intensity of the grass tested in the study. Also the results of Wiśniewska-Kadżajan (2013) clearly indicate that the colour of turf lawns strongly affected by weather conditions.

Throughout all growing seasons it turned out that in the spring, grass was the greenest in 2015, in summer in 2014 and 2015 but in autumn in 2013. In the studies by other authors (Jankowski et al., 1999; Grabowski et al., 1999, 2003b) a similar tendency was noticeable at the assessment of lawn colour.

For example, in autumn period high rainfall in September 2013 had a huge impact on grass colour. In the other study of Jankowski et al. (2011d), the lawn colour was also largely dependent on the meteorological conditions. The results obtained indicate that more favorable weather conditions in 2003 had an effect on more intensive and more desirable colour of lawns. The intensity of green colour of leaf blades of lawn turfs in 2003 was to a large extend affected by the most even distribution of precipitation during the growing period.

In the literature concerning lawn turfs there are few studies on the assessment of their colouring. Consequently, it is difficult to relate the results of the present study to other authors.

\section{Conclusion}

In the study grass colour varied over the growing seasons in relation to the grass species (smooth-stalked meadow-grass, perennial ryegrass, red fescue) and the soil conditioner applied. Of all the bio products, Substral application resulted in the most favourable grass colour when used in spring and summer, and Eko-Użyźniacz when applied in autumn. This means that differences in the effects of soil conditioners in different seasons under different weather conditions were difficult to evaluate. However, those results also indicate an interaction between the types of soil conditioner and the meteorological conditions in their effect on grass colour. In all seasons of the year smooth-stalked meadow-grass had the most favourable colour when treated with Substral in spring and summer seasons, and with Eko-Użyźniacz in autumn. Comparing all soil conditioners, grass treated with UGmax had the best colour. This conditioner is composed not only of minerals, but also contains such micro-organisms as lactic acid bacteria, photosynthetic bacteria, Azotobacter, Pseudomonas, yeast, and Actinomycetes. 
From a practical point of view, of all grass species tested in the study, perennial ryegrass had the smallest, most favourable, colour variation during the whole period. In regard to obtained results for future studies should be recommended UGmax for lawn fertilization as well as the other new soil conditioners.

\section{REFERENCES}

[1] Braun, R., Fry, J., Kennelly, M., Bremer, D., Griffin, J. (2016): Colourant application volume and colour persistence on a "Chischolm" zoysiagrass. - Hort Technology 26: 314-319.

[2] Calvo, P., Nelson, L., Kloepper, J. W. (2014): Agricultural uses of plant biostumulants. Plant Soil 383: 3-41.

[3] Chen, Y., Clapp, C. E., Magen, H. (2004): Mechanisms of plant growth stimulation by humic substances: the role of organo-iron complex. - Soil Science and Plant Nutrition 50(7): 1089-1095.

[4] Czeluściński, W., Jankowski, K., Sosnowski, J., Malinowska, E., Wiśniewska-Kadżajan, B. (2017): Effects of trinexapac-ethyl on turfgrass growth and frequency of mowing. Applied Ecology and Environmental Research 15(3): 739-746.

[5] Domański, P. (1998): Methodology of economic value analysis of cultivated plant varieties. Turf grasses: red fescue, tymothy, meadow grass, ryegrass. - COBORU, Słupia Wielka.

[6] Gąbka, D., Wolski, K. (2008): The effect of biopreparations on early stage of growth of selected grass species used for reclamation of municipal waste dumps. - Biostimulators in modern agriculture. Ornamental and special plants. Warszawa, pp. 7-14.

[7] Grabowski, K., Grzegorczyk, S., Benedycki, S., Kwietniewski, H. (1999): Assessment of functional value of selected lawn grasses for sowing of grass surfaces. - Folia Universitatis Agriculturae Stetinensis Agricultura 75: 81-87.

[8] Grabowski, K., Grzegorczyk, S., Kwietniewski, H. (2003a). The evaluation of usefulness of grass species and varieties for recreational lawns in the Masurian Lakeland conditions. - Biuletyn IHAR 225: 295-302.

[9] Grabowski, K., Grzegorczyk, S., Benedycki, S., Kwietniewski, H. (2003b). Functional values of lawn cultivars of Lolium perenne. - Grassland Science in Poland 6: 69-77.

[10] Hamza, B., Suggars, A. (2001): Biostimulants: Myth and Realities. - TurfGrass Trends AUG: 6-10.

[11] Jankowski, K., Ciepiela, G., Jodełka, J., Kolczarek, R. (1999): Comparative analysis of lawn mitures cultivated under conditions of Podlasie. - Folia Universitatis Agriculturae Stetinensis Agricultura 75: 133-140.

[12] Jankowski, K., Czeluściński, W., Jankowska, J., Ciepiela, G. A. (2010): Effect of aquagel on the initial development of turfgrasses and their aesthetical value. - Journal of Research and Applications in Agricultural Engineering 55(2): 36-41.

[13] Jankowski, K., Czeluściński, W., Jankowska, J. (2011a). Effect of hydrogel and type of fertilizer on the turf compactness with varying participation of perennial ryegrass in mixture. - Folia Pomeranae Universitais Technologiae Stetinesis Agricultura 286(18): 13-22.

[14] Jankowski, K., Czeluściński, W., Jankowska, J., Sosnowski, J. (2011b). The effect of hydrogel and different fertilisers on the regrowth rate of lawns composed of perennial ryegrass. - Journal of Water and Land Development 2(34): 73-82.

[15] Jankowski, K., Sosnowski, J., Jankowska, J. (2011c). Effect of hydrogel and different types of fertilizers on the number of turf shoots in lawns created by monocultures of red fescue (Festuca rubra L.) Cultivars and its mixtures. - Acta Agrobotanica 64(3): 109118. 
[16] Jankowski, K., Jankowska, J., Sosnowski, J.,(2011d). Colouring of lawns established on the basis of red fescue depending on application of superabsorbent and various fertilizers.

- Folia Pomeranae Universitais Technologiae Stetinesis Agricultura 10(3): 67-75.

[17] Jankowski, K., Jankowska, J., Czeluściński, W. (2012a). Lawn colours in the aspect of hydrogel and mineral fertilizers applied. - Acta Scientiarum Polonorum 11(1): 43-52.

[18] Jankowski, K., Czeluściński, W., Jankowska, J., Sosnowski, J. (2012b). Colouring of turf lawns after application of different doses of mushroom refuse. - Grassland Science in Poland 15: 77-85.

[19] Knot, P., Hrabe, F., Hejduk, S., Skladanka, J., Kvasnovsky, M., Hodulikova, L., Caslavova, I., Horky, P. (2017): The impacts of different management practices on botanical composition, quality, colour and growth of urban lawns. - Urban Forestry \& Urban Greening 26: 178-183.

[20] Pooya, E. S., Tehranifar, A., Shoor, M., Selahvarzi, Y., Ansari, H. (2013): The use of native turf mixtures to approach sustainable lawn in urban landscapes. - Urban Forestry \& Urban Greening 12: 532-536.

[21] Prończuk, S., Żurek, D. (2008): The relationship between sod strength and turf quality of common grass cultivars. - Bulletin of Plant Breeding and Seed Science 57: 25-34.

[22] Salehi, H., Khosh-Khui, M. (2004): Turfgrass monoculture cool-cool and cool-warm season seed mixture establishment and growth responses. - HortScience 39(7): 17321735 .

[23] Skowera, B., Puła, J. (2004): Pluviometric extreme conditions in spring season in Poland in the years 1971-2000. - Acta Agrophysica 3(1): 171-177.

[24] Starczewski, K., Starczewska-Affek, A. (2011): Effect of agronomic factors on the perennial ryegrass lawn colour. - Acta Scientiarum Polonorum Agricultura 10(2): 117125.

[25] Stępczak, K. (1997): Environmental Protection and Shaping. - WSiP, Warszawa.

[26] Systematics of Polish Soil (2011): Roczniki Gleboznawcze. - Annals of Soils Science 62(3): 1-193.

[27] Talar-Krasa, M., Świerszcz, S. (2015): The influence of using biostimulant on the visual quality of turf. - Episteme 26(2): 365-373.

[28] Wiśniewska-Kadżajan, B. (2013): Effect of different mushrooms substrate dose on the general aspect and colour of turf lawns. - Fragmenta Agronomica 30(3): 183-192.

[29] Wolski, K. (2003): The importance of grasses in human life and environmental protection. - PTNA, WTN Wrocław, pp. 1-10. 